\title{
Mass Disaster Victim Identification: The Tsunami Experience
}

\author{
Jean-Pol Beauthier ${ }^{1, *}$, Edd,y De Valck ${ }^{2}$, Philippe Lefevre ${ }^{3}$ and Joan De Winne ${ }^{4}$
}

${ }^{1}$ Medico-legal Unit, Laboratory of Anatomy, Biomechanics and Organogenesis - Faculty of Medicine, Université Libre de Bruxelles (U.L.B.) - Campus Erasme CP 629 - Lennik street 808 - B 1070 Brussels - Belgium; ${ }^{2 .}$ Forensic odontologist - Belgium; ${ }^{3}$ Laboratory of Anatomy, Biomechanics and Organogenesis - Faculty of Medicine, Université Libre de Bruxelles (U.L.B.) - Belgium; ${ }^{4}$ Federal Police Belgium - Commanding Officer DVI Team - Brussels - Belgium.

\begin{abstract}
One of the most important reasons to identify unknown persons is because non-identification may result in numerous issues at emotional and legal level for the surviving family members and friends.

To reach a level of scientific supported positive identification, which can withstand international legal scrutiny, the identification process of mass disaster victims requires a well-structured and pre-planned management based upon the international Interpol DVI Standing Committee guidelines. The handling of the December 2004 Tsunami disaster, affecting people of different nationalities and ethnic origins, will be used as an example to illustrate this methodology and standard operating protocols which can be used under similar circumstances.

The activities of the Belgian DVI Team in the Khao Lak area, as part of the multinational help force bringing assistance to the local Thai law enforcement agencies, is discussed.

Taking part in the first operations of identification, we were confronted with the hard reality of the hugeness of this planetary tragedy having made on the whole more than 200,000 victims.

Differences in composition of the teams and their working philosophies are illustrated, based on the experience of the Belgian multidisciplinary team including scientific forensic experts (pathology, anthropology, odontology), police officers, members of the civil protection (with their technical capabilities in particular working conditions), but also a physician, a nurse and a stress team.
\end{abstract}

Some of the applied methods and techniques used in the identification process were reviewed and suggestions given about how improvements can be made for future reference.

Keywords: Forensic pathology, mass disaster, DVI, identification, tsunami, interpol forms.

\section{INTRODUCTION}

The proper identification of a decedent is not only important for humanitarian and emotional reasons for the next-ofkin but also for legal and administrative purposes. However, this identification issue that can withstand legal scrutiny, represents one of the most difficult medico-legal and anthropological tasks. All possible means must be applied to achieve a scientific identification, which is sometimes extremely difficult, particularly in mass disaster situations [1-3] or in matters of genocide crimes.

For some the mourning process starts as soon as the family members are aware of the suspected loss but the positive identification of the decedent also may be needed and helpful with so-called "closure". Some families feel that the uncertainty is more difficult to cope with than the definitive

*Address correspondence to this author at the Charleroi Medico-Legal Center, Masses-Diarbois street 112, B - 6043 Charleroi - Belgium;

Tel: 0032713592 22; Fax: 0032713541 54;

E-mail: jean-pol.beauthier@ulb.ac.be

1874-4028/09 identification. From both legal and administrative points-ofview, non-identification creates additional problems.

Regardless of the body's condition, the forensic and anthropological methods used during the different stages of the identification process must be rigorous and systematic $[4,5]$.

According to the American Board of Anthropology, "forensic anthropology is the application of the science of physical anthropology to the legal process. The identification of skeletal, badly decomposed, or otherwise unidentified human remains is important for both legal and humanitarian reasons. Forensic anthropologists apply standard scientific techniques developed in physical anthropology to identify human remains and to assist in the detection of crime" [612].

Following the discovery of skeletal remains, the physical anthropologist's aim is to prove their origin by studying rituals of burial, ancestry, and osseous characteristics which can provide interesting information on lifestyle, occupational activities, or hierarchical status. The forensic anthropologist can use the same methods for the purposes of identifying victims and uncovering medico-legal clues as to the criminal nature of a death. 
We will use as an example, the forensic activities of the Belgian DVI team ${ }^{1}$ in Thailand during the identification of the Tsunami victims.

\section{THE DISASTER}

The massive Sumatra - Andaman earthquake achieved a magnitude of 9.0 on the Richter scale. Its epicenter was located off the West coast of Northern Sumatra and was responsible for the tsunami of December 26, 2004 [13-15]. The Tsunami brought serious damage to people, properties, communities and natural resources not only in Thailand but also in many other countries around the Indian, Bengal and Andaman oceans (Table 1) [16].

\section{COMPOSITION OF BELGIAN DVI TEAM}

The Belgian DVI Team is in fact split into three main subteams: an ante mortem (AM) team, a post portem (PM) team and a logistics support team. When DVI team is also charged with collecting victims on site of autopsy, this activity is done by a fourth separate "necrosearch" team.

For a proper post mortem (PM) examination and from a logistic point of view, it is recommended that a DVI team be multidisciplinary so that, immediately after deployment and regardless of local conditions and facilities, it can operate autonomously. This requires not only the presence of specialized forensic experts on the team but also a strong added value of auxiliary personnel.

The Belgian DVI team is composed of (i) policemen specialized in recovery/exhumation, logistics and/or administration, scientific laboratory and photography (ii) forensic medical examiners (ideally with forensic anthropology specialization), (iii) forensic odontologists, (iv) members of a civil protection unit for body care and transport, and for assisting with the deployment and use of heavy equipment or machinery, (v) a psychologist trained in post-traumatic stress disorder (PTSD) and available for the team at all times, (vi) and a medical doctor and registered nurse to attend to all team members' medical needs (Table 3). Such kind of post mortem DVI team with adequate material will be selfsupporting and can be operational within a few hours after arrival at a mass disaster scene.

The collection of ante mortem (AM) material is handled by police officers, medical examiners and forensic odontologists who try to obtain information from the missing person's families and practitioners. The AM DVI team is usually composed of 5 policemen, but also includes Red Cross members, psychologists and social assistants.

In Thailand, the Belgian DVI team was assigned to "Wat Yan Yao", a Buddhist temple in Takua pa village, near Khao Lak beach, as part of the world wide DVI community effort to assist the Thai government in identifying victims. So, the Belgian Disaster Victim Identification Team (DVI Team) worked in close collaboration with other international DVI teams from Australia, New Zealand, the USA, Singapore, China, Great Britain, Scandinavia, France, Netherlands, Germany and Austria at the Khao Lak site (Phang-Nga province) in Thailand (Fig. 1).

\footnotetext{
${ }^{1}$ Belgian Disaster Victim Identification Team.
}

Table 1. Dead and Missing Persons' Distribution

\begin{tabular}{|c|c|}
\hline Countries & Victims \\
\hline \hline Sri Lanka & $\begin{array}{c}\text { m8,940 (combined dead, presumed dead and } \\
\text { missing) }\end{array}$ \\
\hline India & 10,672 and 5,600 missing (Andaman Islands) \\
\hline Indonesia & 69 \\
\hline Thailand & $\begin{array}{c}5,395 \text { (Thais: } 1,972 \text {; foreign nationals from at } \\
\text { least } 36 \text { countries: } 2,248 ; \text { and } 1,175 \text { of unknown } \\
\text { nationality) and } 2,817 \text { missing (Thais: } 1,924)\end{array}$ \\
\hline Malaysia & 61 \\
\hline Myanmar & 82 \\
\hline Maldives & 2 \\
\hline Bangladesh & 298 \\
\hline Somalia & 10 \\
\hline Tanzania & 1 \\
\hline Kenya & $>232,000$ (combined) \\
\hline Total & 600 missing \\
\hline
\end{tabular}

Table 2 lists the number of dead per Thai province from the two tables, (e.g. under Table 2).

Table 2. Death Repartition by Thai Provinces

\begin{tabular}{|c|c|}
\hline Province & Deaths \\
\hline \hline Phan-Nga & 4,225 \\
\hline Krabi & 721 \\
\hline Phuket & 279 \\
\hline Ranong & 159 \\
\hline Satun & 6 \\
\hline Trang & 5 \\
\hline Total & 5,395 \\
\hline
\end{tabular}

The first Belgian DVI Team arrived in Phuket on January 2, 2005 and a second team followed two weeks later when the first team returned home. A few team members worked during several months in data base organization at the Thai Tsunami Victim Identification Information Management Centre (TTVI-IMC) in Phuket.

\section{METHODOLOGY OF BODY EXAMINATION}

Body recovery had been carried out by the local Thai population prior to the time of the Belgian team arrival in Thailand, January 2, 2005, and the bodies were stored at Wat Yan Yao (Site 1A) awaiting the start of the identification process. After the first logistic problems were solved - electricity and water supply, air-conditioning, protected space for the autopsy room - the PM identification line was divided into four work sections: fingerprinting, medical examination, odontology examination and DNA sampling (Fig. 2). 
Table 3. Away DVI Belgian Team Complete Composition with Two Operational Simultaneous Lines (for Max. 3 Week Rotation)

\begin{tabular}{|c|c|c|}
\hline & 1 Team leader & \\
\hline & 1 assistant team leader & \\
\hline & 1 logistics member & \\
\hline & $1 \mathrm{AM}$ and Identification coordinator & \\
\hline & $\begin{array}{l}1 \text { Officer for international Management Cen- } \\
\text { ter }\end{array}$ & \\
\hline & 1 Medical doctor & \\
\hline & 1 paramedical member (nurse) & \\
\hline & 1 psychologist & \\
\hline PM line 1 & & \\
\hline & & PM line 2 \\
\hline 1 chief line officer & & 1 chief line officer \\
\hline $\begin{array}{l}1 \text { pathologist }+1 \text { DVI policeman (to help } \\
\text { write documents and reports) }\end{array}$ & & $\begin{array}{l}1 \text { pathologist + } 1 \text { DVI policeman (to help write docu- } \\
\text { ments and reports ) }\end{array}$ \\
\hline $\begin{array}{c}1 \text { odontologist }+1 \text { DVI policeman (to help } \\
\text { write documents and reports) }\end{array}$ & & $\begin{array}{l}1 \text { odontologist + } 1 \text { DVI policeman (help in writing docu- } \\
\text { ments and reports) }\end{array}$ \\
\hline $\begin{array}{l}1 \text { science laboratory policeman (for finger- } \\
\text { printing) }\end{array}$ & & 1 science laboratory policeman (for fingerprinting) \\
\hline $\begin{array}{l}1 \text { DVI policeman (for washing and identify- } \\
\text { ing clothing, documents, jewelry...) }\end{array}$ & & $\begin{array}{l}1 \text { DVI policeman (for washing and identifying clothing, } \\
\text { documents, jewelry...) }\end{array}$ \\
\hline $\begin{array}{l}1 \text { DVI policeman for completing PM Inter- } \\
\text { pol documents }\end{array}$ & & 1 DVI policeman for completing PM Interpol documents \\
\hline 1 Belgian Civil protection member & & 1 Belgian Civil protection member \\
\hline & 1 DVI photographer & \\
\hline$\rightarrow$ & $\begin{array}{l}1 \mathrm{DVI} \text { member for collecting all informa- } \\
\text { tion/documents/samples on final desk }\end{array}$ & $\leftarrow$ \\
\hline
\end{tabular}

Fingerprinting was very difficult due to the condition of the bodies but was successfully realized by specialists of the technical and scientific laboratories of the different national law enforcement agencies. Finger skin was removed by careful "degloving" and placed on the fingertip of one of the two operators (Fig. 3). After powdering, the fingerprints were then transposed onto paper. The use of separated fingerprinting rooms proved to be very practical and useful.

After fingerprinting, the body was then transferred to the air-conditioned autopsy room, where external and internal descriptions took place. Clothing, jewelry and other personal objects were systematically removed, cleaned, described and photographed alongside a metric scale and the corresponding body number.

The external body examination allowed for (i) height determination; (ii) description of tattoos, scars, anatomical and/or sequel characteristics, congenital abnormalities, as well as recent or old traumatic elements; (iii) description of discernable physical characteristics (e.g. cranial hair color and thoracic, axillar, arm and pubic hair description...).

According to international agreements and recommendations decided at multiple the staff meetings, the internal autopsy performed in Thailand was limited to the abdominal cavity, checking for the presence/absence of the gall bladder, appendix, genitalia, etc. Any abnormal anatomic findings were further investigated with more extensive examination (e.g. dissection of a uterine tumor, description of tubar clips, intra-uterine devices, etc.).

To facilitate the work of the odontologists during the further part of the autopsy, it was essential to create a mandibular access (Figs. 4, 5, 6 and 7). We used a dissecting technique consisting of a semicircular incision, from ear to ear, behind each mandibular angle and passing through the anterior cervical region, under the submental area.

The cutaneous flap was reclined upwards onto the face using a Senn-Miller retractor allowing for the exposure of the temporomandibular joints.

A second incision was made along the internal border of the mandibular body, cutting the muscles of the buccal floor, making it possible to release the lingual block. The muscles were sectioned on the mandible.

The m. masseter was cut at the level of the goniac angle and the corpus mandibulae. The $m$. temporalis was sectioned at the processus coronoideus of the mandible, while the $\mathrm{mm}$. pterygoidei were progressively dissected with the blade of the scalpel following the articular structures, when the mandible was separated at the level of the temporomandibular 


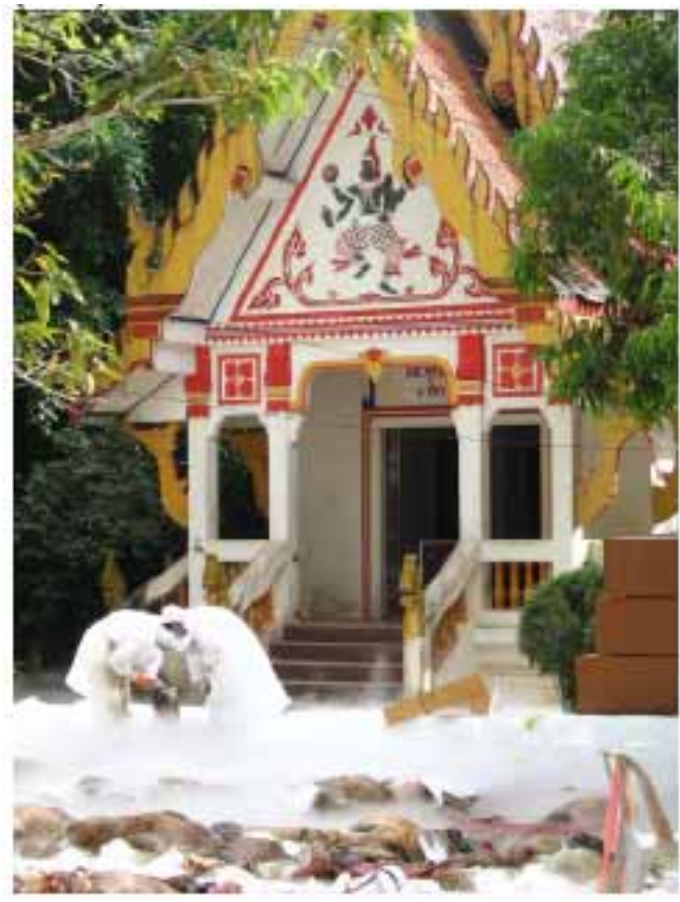

Fig. (1). The accumulated bodies were protected by dry ice prior to autopsy (Wat Yan Yao Site 1a - Khao Lak).

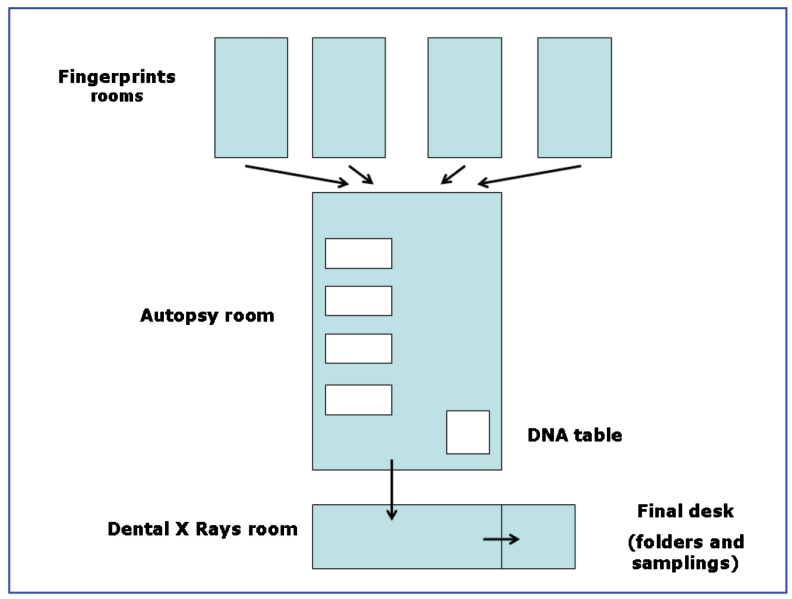

Fig. (2). Organization of the first autopsy room.

joint. The end result of this modified Keiser-Nielsen method [17] was a free and intact mandible.

This technique facilitated the forensic odontologist's PM work, as it created an easy access to both the maxillar and mandibular dentition. Separate pictures were taken of the upper jaw, lower jaw and teeth in occlusal position, as well as with articulating jaws. The complete dentition was described (Fig. 8) using Interpol protocols, nomenclature and forms $[18,19]$, with distinction between sound, pathological, restored and missing (ante mortem or post mortem) teeth, attrition and oral anatomical abnormalities. All the observations were carefully registered on pages F1 \& F2 (Interpol PM form) and marked on the odontogram of the post mortem pink form.

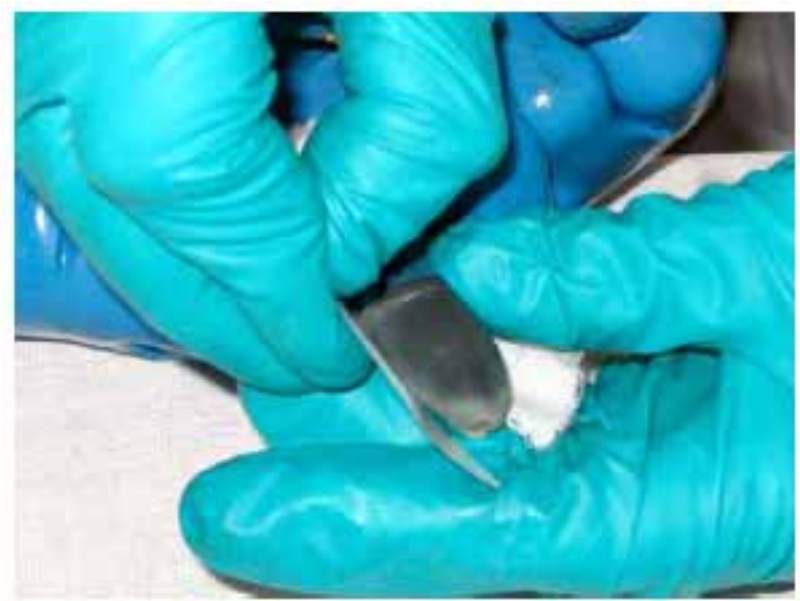

Fig. (3). Glove-on' fingerprinting technique.

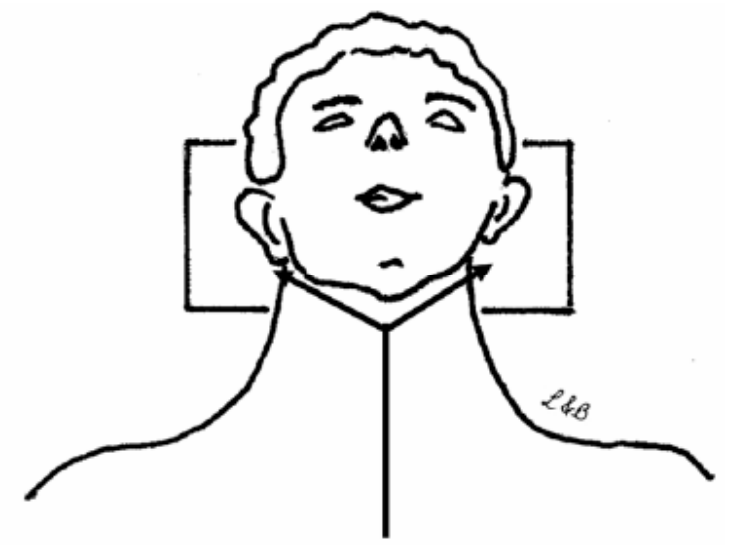

Fig. (4). Dissection technique for easy access to both upper and lower maxillary jaws. Anterior view.

Step A: general cutaneous incisions.



Fig. (5). Dissection technique. Lateral view.

Step B: muscle section.

1: m. masseter, pars superficialis et pars profunda.

This particular and meticulous dissection technique also enabled the reposition of the mandible and an easy complete 


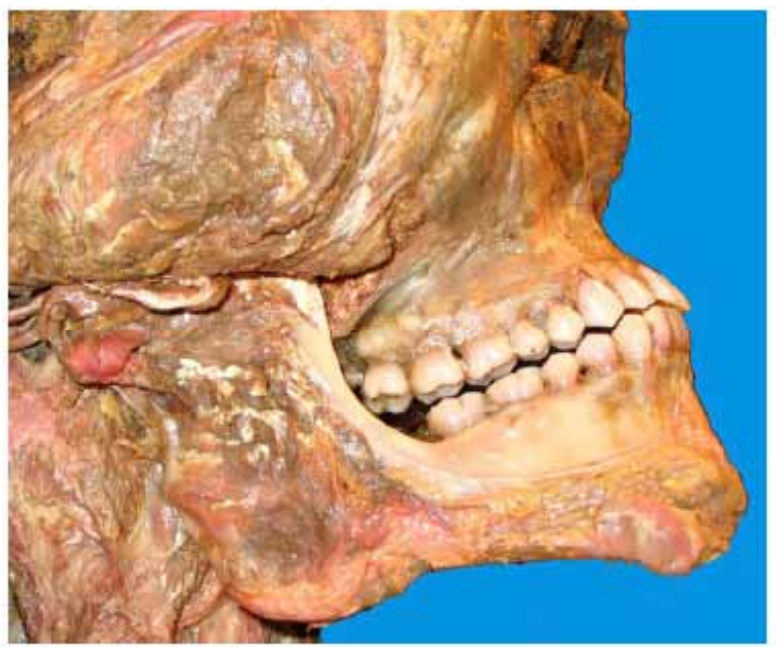

Fig. (6). Dissection technique. Lateral aspect of the mandible after steps A \& B.

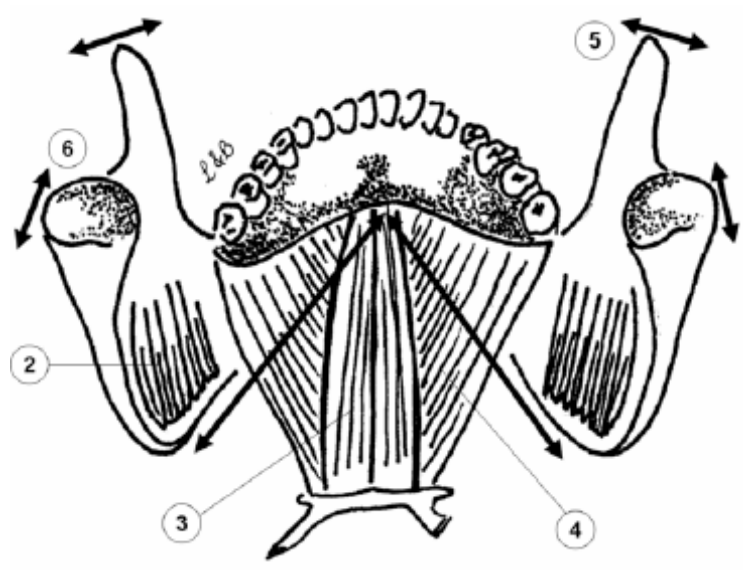

Fig. (7). Dissection technique. Craniodorsal view of the mandible.

Step C: muscles sections along the inner (medial) border of the mandible.

2: m. pterygoideus medialis;

3: m. geniohyoideus;

4: m. mylohyoideus;

5: section of the coronoid insertion of the m. temporalis;

6: disarticulation of the temporomandibular joint.

facial reconstitution by simply folding back the cutaneous facial tissues. This allowed an eventual showing of the victim to family members in a post identification stage if requested.

Because of the rapid decomposition and subsequently muscular alterations, a sampling of the femoral shaft (recommended for DNA analysis) was carried out by the anthropologist. This happened in a separated area of the main autopsy room, using clean tools different from those used during autopsies. Another possibility for DNA sampling was the extraction of two sound teeth that contain sufficient pulp material inside these teeth, preferably two premolars or canines.

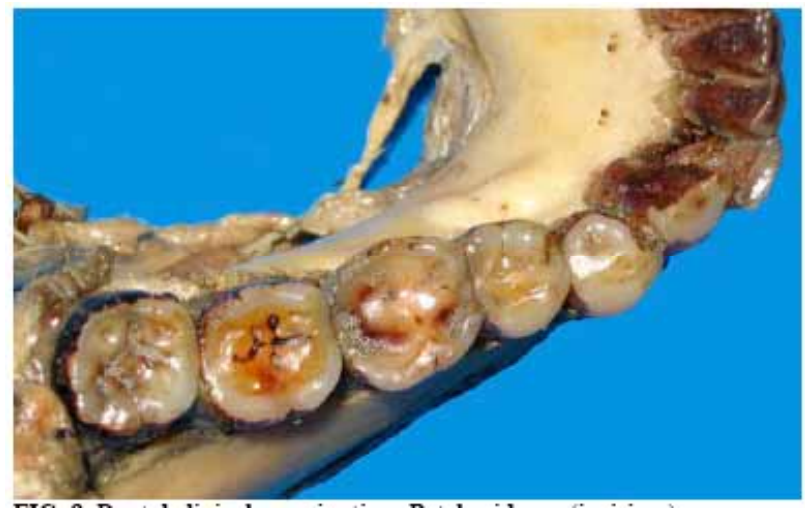

Fig. (8). Dental clinical examination: Betel evidence (incisives).

The body was then transferred to the next room, where the odontologists took dental radiographies (bite wing radiographies, and $\mathrm{X}$-rays of individual dental particularities) (Fig. 9).

During the first few weeks, only conventional dental Xray equipment was available, but in a later stage a Nomad ${ }^{\mathrm{TM}}$ handheld digital dental X-ray machine was made available, considerably facilitating the odontologist's task..

The post mortem work was very intense, not only because of the number of victims but also because of time restrictions for post mortem examination, allowing only 20 min for each work section: fingerprinting, medical examination, odontological examination.

The causes of death of the tsunami victims examined by the Belgian team were exclusively drowning and blunt trauma which coincides with the conclusions of the German DVI team [3]. See also the conclusions concerning major wounds and complications following near drowning on survivals [20].

A fundamental place in the PM information gathering was located at the final desk by (i) checking if all examinations were carried out; (ii) checking correspondence of all numbered samples with the given body number; (iii) ensuring exploitable quality of the dental X-rays after development and (iv) quality control of all documents.

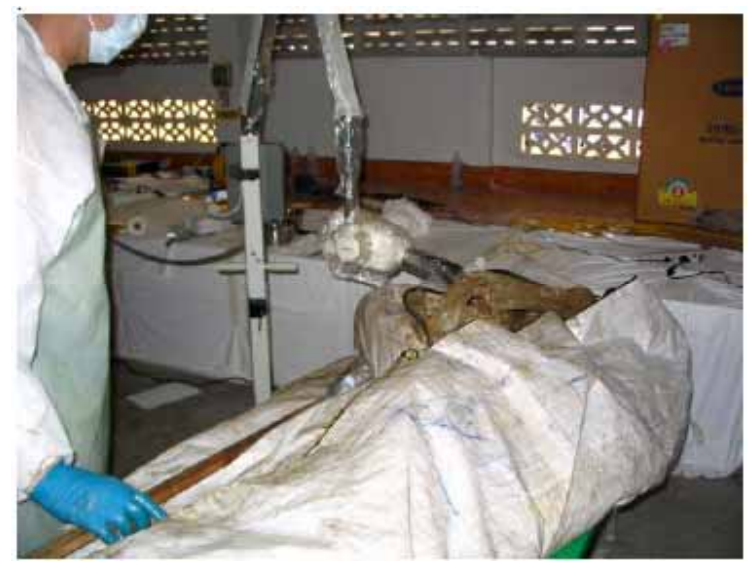

Fig. (9). Long Cone Dental X-Ray technique, before portable digital equipment became available. 
Only after meeting all these quality criteria could the body be carried out of the technical autopsy rooms and stored in an appropriate refrigerated container, where its exact location was registered by the body handler (Fig. 10).

\section{THE IDENTIFICATION PROCESS}

Reconstructive identification is a prerequisite to comparative identification.

During the reconstructive identification process all necessary information (physical attributes, medical and dental clues, DNA, fingerprints...) is gathered from the unknown body of the victim so that an objective reconstructed profile can be established. This reconstructed PM profile can then be matched with missing persons' AM information for a comparative identification.

The Interpol DVI Standing Committee developed DVI Guidelines in the 1980's to promote the use of standardized $\mathrm{AM}$ and $\mathrm{PM}$ forms across personal and national preferences in all member countries [21]. These Interpol AM and PM forms are completed separately. Only in a later stage are the $\mathrm{AM}$ and PM information cross checked in order to lead to a final identification.

During the different stages of the PM body examination, all useful elements for identification are systematically indexed on the pink PM Interpol form, by the multidisciplinary team performing the autopsy.

The AM data are collected from each presumed victim's family. This information can be collected at their home or at a place where the family members are gathered, close to the disaster scene or at a distant location, according to the type of disaster and/or the wishes of the families. Further and/or more specific information will then be collected from friends and acquaintances, the missing person's employer, doctor or dentist. It is also important to obtain pictures of the presumed victims and to collect their fingerprints.

Hair samples, toothbrushes or other personal belongings of the missing person that can be useful to determine a DNA profile will be searched for and collected.

The family lineage will be established to determine from which relatives blood or saliva samples must be collected in case DNA analysis will be necessary for victim identification.

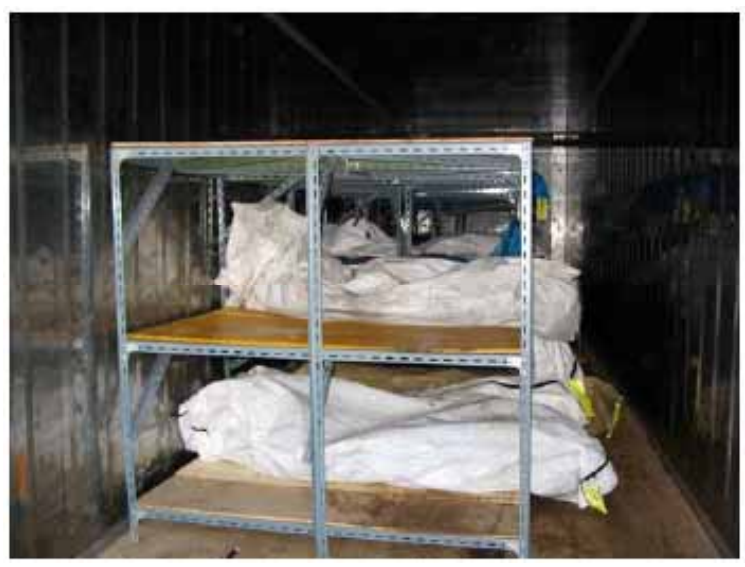

Fig. (10). Containers and repertory of PM examined bodies.
AM fingerprints are collected at the homes of the presumed victims from objects likely only touched by them (e.g. a perfume bottle for women or an after shave bottle for men).

The AM forms (yellow) are completed by the team contacting the alleged victim's family and collecting (i) medical and surgical antecedents, (ii) morphological characteristics, (iii) professional antecedents and characteristics that result from these, (iv) dental information [22], (v) description of clothing, jewelry, and other personal objects worn by the missing person, (vi) missing person's pictures.

All collected AM data - even partial - are transmitted to the Identification Section and transcribed into the computer data file. The computer team works with the "DVI International" software program, developed by PlassData ${ }^{\mathrm{TM}}$ and used by the Interpol DVI Community worldwide. This software program allows research and automatic comparisons between AM and PM data bases in both directions: AM to PM or vice versa. [23-25].

The by-the-computer-suggested correspondences between an unidentified body and a missing person facilitate a more specific manual control and comparison of the corresponding AM and PM data by a team of specialists.

This team informs the Chief of the Identification Team about a final decision on the identity of the unidentified human remains.

The rigid application of and the respect for the Interpol International Conventions (e.g. the dental classification and the symbols used for a correct registration of the various dental treatments) enabled an optimal procedure leading to the positive identification of these innumerable victims [22].

The actual Interpol forms currently also contain an important DNA document, indicating the methods and the markers to be used, in order to allow a uniform comparative application at an international level [26].

In Thailand, at the end of the first week, was created the Thai Tsunami Victim Identification committee (TTVI) in order to establish Standard Operation Protocols for data collection and identification procedures [3].

The Thai Tsunami Victim Identification Information Management Center (TTVI - IMC) under the direction of the Royal Thai Police [27], coordinated the collaboration between the international Disaster Victim Identification Teams and Thai authorities.

Once all PM and AM data were entered into PlassData ${ }^{\mathrm{TM}}$, the system conducted a daily automatic search to identify possible matches. These were then manually verified by members of the reconciliation team to confirm the potential identity of a victim. All information used in the comparison process was then compiled and presented to the Reconciliation Board, composed of specialists from all areas of forensic and investigative expertise, for final confirmation. Once identification was confirmed, a death certificate was issued and the body released [28]. The national authorities of the victim's country were then contacted so that the victim's family could be informed about the positive identification, and so that the repatriation process could begin. 


\section{DISCUSSION AND SUGGESTIONS FOR FUTURE IMPROVEMENTS}

While working at Wat Yan Yao, Site 1a during the course of our working period, we observed a change in the numbering system of the bodies.

From an administrative point of view, we believe that it is imperative to adopt a single and definitive numbering system for each unidentified body, from the beginning of an operation. This should be determined by the management in a Standard Operating Protocol (SOP).

For the same reason, the teams must be deployed to the disaster site as soon as possible. Early body examinations, a fast and unique numbering system, and the possibility of taking pictures at the scene of death before body removal, will considerably improve the chances of a positive identification.

Depending on the type of PM examinations to be performed on the bodies it might be very useful to conduct the medico-legal and anthropological examinations as close to the disaster site as possible. This helps to avoid destruction or loss of evidence caused by body transport (loss of teeth of particular bones that could be useful in criminal investigations, such as the hyoid bone...). The utility of "field mortuaries" in Kosovo was previously described by Beauthier et al. [29]

As for the autopsy room management, all DVI teams deployed and working in that place should accept the agreed upon conditions (SOPs) and these conditions really are the rules of engagement. The presence onsite of a chief autopsy room manager, supervising all examination activities of the different teams as well as managing the arrival of new bodies, has proved to be of exceptional added value. At the same time, this person should have the power to enforce the SOPs and take any necessary actions should problems occur.

A chief DNA manager can operate away from the main autopsy room. This DNA manager would be responsible for the sampling of the DNA femoral shafts and making sure there is no permutation of the Interpol forms corresponding to the bodies.

On a DNA level, it is useful to systematize the sampling of the dental and femoral diaphysis parts. In Thailand costal samples were taken from numerous bodies in the early days, but at a later stage instructions were given to start all over and instead collect the SOP approved femoral samples and/or teeth.

The authors are well aware of the limitations of the external body examination.

In this particular case and because of the body conditions the search for scars for example proved to be inadequate, but tattoos however were more easily detected and of great value.

The assistance of the local Thai auxiliary personnel in interpreting or translating some of the tattoos proved invaluable.

The benefits of a separate X-ray room [30] where radiological examination of the body by X-ray amplification would allow to locate the presence of foreign bodies (e.g. osteosynthesis, prosthesis, tubar clips, vascular stents or pacemakers) are without any doubts and this idea should be taken into consideration at all times.

Radiology could be complementary or even replace the limited internal autopsy which provided very little helpful information as to validly evaluate anatomical characteristics under these difficult conditions [31].

For the same reasons it was often almost impossible to determine ethnic groups ${ }^{2}$ as was requested during the initial working days at Wat Yan Yao.

According to some the Interpol odontograms can be tiresome to complete, in particular in relation to the required various color schemes that are indicative of the different materials used during treatment.

Since the computer program, PlassData ${ }^{\mathrm{TM}}$ DVI System International, automatically transcribes the colors according to the designated materials, it seems unnecessary to have to manually mark them on the Interpol F2 form.

Also, some users estimated that there are too many abbreviations listed for practical use. Simplifying the existing protocols and guidelines for odontological examination and registration seems necessary and appropriate and has been implemented by PlassData ${ }^{\mathrm{TM}}$ in their latest version of DVI System International after consulting with the international forensic odontology community.

A final desk at the very end of the examination line is absolutely fundamental. The final desk manager has to make sure that the PM folders are complete and correctly numbered, including the femoral or teeth sampling for DNA, quality control of dental X-rays and dental pictures [32,33], clothing and jewelry pictures, and body particularities (scars, tattoos) pictures. He or she has the final clearance authority for body transfer to the storage container.

The efficiency of the adopted methodology is strictly depending on the kind and nature of the mass disaster. Each disaster is different and the approach adapted accordingly.

The final identification results depend mainly on the presence and quality of the AM information and in particular availability of physical evidence such as ante mortem X-rays $[32,34,35]$, fingerprints [28], dental records [22, 33, 2] and of course DNA, [36].

In 2006 Perrier, noted the effectiveness of the different methods in identifying the Phuket victims: $73 \%$ for odontology, 24\% for dactyloscopy and 3\% for DNA analysis [37] with similar conclusions reported by Sribanditmongkol et al. about reconciled Thai victims by primary evidence under TTVI $[38,39]$. The predominant role of forensic odontology was also underlined by Kirsch et al: from 478 German victims identified, $400(83.7 \%)$ were identified by dental status, $63(13.2 \%)$ by fingerprints, 15 (3.1\%) by DNA [40].This highlights the need to first focus on simple, inexpensive and time-efficient methods, of course without minimizing the value of fingerprints and the excellence of DNA which are decisive in the identification process [23, 41, 24, 42-48, 3].

In December 2008, The Thai Tsunami Victim Identification and Repatriation Center mentioned that 388 bodies re-

\footnotetext{
${ }^{2}$ Biological groups or geographical origin.
} 
main unidentified from the Thai tsunami. Center Director Nitinai Sornsongkram explained that the center had received 3,696 bodies in February 2005. In these late recovered bodies, 3,308 were eventually returned to their families. Despite a long time since the tsunami, Sornsongkram said that center officials were still trying to identify the 388 remaining victims [49].

The usefulness of the presence of a medical doctor specialized in emergency medicine and reanimation and a nurse - standard in the Belgian DVI team - was shown clearly the presence during our work at Wat Yan Yao. Indeed, one of the team members noticed the need for medical assistance to a US voluntary who had isolated himself outside one of the rooms of the Buddhist temple. He was obviously going into an epileptic condition subsequent to a heat stroke. He was immediately taken care of and medicated by our team, reanimated, and placed on an infuse during several hours. He regained conscience and rejoined his team, very happy to have survived this condition which could have been fatal without the quick intervention of the Belgian medics.

Another quick intervention of the medical team proved to be extremely effective following a severe wound on the level of a lower limb suffered by one of the Belgian team members after taking a bad fall. Local and general care was immediately given and the casualty evolved favorably.

When it comes to the presence of member(s) of the stress team, it was true that the majority of the members of the Belgian DVI Team in Thailand were veterans of many mass disasters and that did not need psychological assistance. However the presence of specialized psychologists might be very useful when rookie or junior team members are facing the psychological impact of the work during an event of this kind. All of us remember without any doubt their first involvement and the impact it made during the work an in the aftermath of a disaster. A stress team that works and lives with the team during the disaster will be able to provide more adequate assistance when needed.

\section{CONCLUSIONS}

Adequate victim identification management goes through strict methodology and protocols. This requires adopting and applying standard operating protocols, in agreement with the Interpol DVI Standing Committee guidelines.

The need for such requirements is amplified when confronted with a mass disaster affecting people of different nationalities and ethnic origins, such as the December 26, 2004 tsunami.

Such an undertaking requires a multidisciplinary team with a composition similar to the Belgian DVI Team, which in addition to scientific experts, includes a significant number of police officers able to a wide range of tasks and capable of efficiently assisting the team's scientific personnel. Members of the civil protection units are also extremely useful, bringing in their technical knowledge and skills to improve the overall working conditions.

In addition, the Belgian DVI team is probably one of the only teams in the world to have a physician, a nurse, a psychologist and a stress team as regular team members.
The expertise in relation to disaster victim identification is enhanced when team members, working together in an interdisciplinary way, share mutual respect, are professionally trained and skilled, and have multi-functional capabilities.

\section{ACKNOWLEDGMENTS}

We wish to thank Laurence Genevrois and Denise De Valck - Crenwelge (USA, BS Journalism, 1980, Texas A\&M University) for their assistance as translator and editor respectively.

\section{NOTE}

Please note that all the photographs are the property of J.P. Beauthier. The (Figs. 4, 5 and 7) are the property of J.P. Beauthier and $\mathrm{Ph}$. Lefevre.

\section{REFERENCES}

[1] Lunetta, P.; Ranta, H.; Cattaneo, C.; Piccinini, A.; Niskanen, R.; Sajantila, A.; Penttila, A. International collaboration in mass disasters involving foreign nationals within the EU: medico-legal investigation of Finnish victims of the Milan Linate airport SAS SK 686 aircraft accident on 8 October 2001. Int. J. Legal Med., 2003, 117(4), 204-10.

[2] Poisson, P.; Chapenoire, S.; Schuliar, Y.; Lamant M.; Corvisier, J.M. Four major disasters in Aquitaine, France: use of odontologic techniques for identification. Am. J. Forensic Med. Pathol., 2003, 24(2), 160-3.

[3] Tsokos, M.; Lessig, R.; Grundmann, C.; Benthaus, S.; Peschel, O. Experiences in tsunami victim identification. Int. J. Legal Med., 2006, 120(3), 185-7.

[4] Djuric, M.; Dunjic, D.; Djonic, D.; Skinner, M. Identification of victims from two mass-graves in Serbia: a critical evaluation of classical markers of identity. Forensic Sci. Int., 2007, 172(2-3), 125-9.

[5] Djuric, M.P. Anthropological data in individualization of skeletal remains from a forensic context in Kosovo--a case history. J. Forensic Sci., 2004, 49(3), 464-8.

[6] Baccino, E. Forensic Anthropology Society of Europe - A section of the International Academy of Legal Medicine [newsletter]. Int. J. Legal Med., 2004, 118(4), N1.

[7] Cattaneo, C. Forensic anthropology: developments of a classical discipline in the new millennium. Forensic Sci. Int., 2007, 165(23), 185-93.

[8] Cattaneo, C.; Baccino, E. A call for forensic anthropology in Europe [newsletter]. Int. J. Legal Med., 2002, 116(1), N1-N2.

[9] http://www.all-about-forensic-science.com/forensicanthropology.html.

[10] http://www.kathyreichs.com/forensics.htm.

[11] http://www.theabfa.org/index.html.

[12] http://www.tncrimlaw.com/forensic/f_anthro.html.

[13] http://ublib.buffalo.edu/libraries/asl/guides/indian-oceandisaster.html.

[14] Lay, T.; Kanamori, H.; Ammon, C.J.; Nettles, M.; Ward, S.N.; Aster, R.C.; Beck, S.L.; Bilek, S.L.; Brudzinski, M.R.; Butler, R.; DeShon, H.R.; Ekstrom, G.; Satake, K.; Sipkin, S. The great Sumatra-Andaman earthquake of 26 December 2004. Science, 2005, 308(5725), 1127-33.

[15] Neetu, S.; Suresh, I.; Shankar, R.; Shankar, D.; Shenoi, S.S.; Shetye, S.R.; Sundar, D.; Nagarajan, B. Comment on "The great Sumatra-Andaman earthquake of 26 December 2004". Science, 2005, $310(5753), 1431$.

[16] http://www.coe-dmha.org/Tsunami/Tsu111705.htm

[17] Keiser-Nilsen, S. Person identification by means of teeth. John Wright and Sons Ltd, Bristol, 1980.

[18] Bajaj, A. Disaster victim identification: Tsunami. Br. Dent. J., 2005, 198(8), 504-5.

[19] Sweet, D. Solving certain dental records problems with technologyThe Canadian solution in the Thailand tsunami response. Forensic Sci. Int., 2006, 159(Suppl), S20-3. 
[20] Prasartritha, T.; Tungsiripat, R.; Warachit, P. The revisit of 2004 tsunami in Thailand: characteristics of wounds. Int. Wound J., 2008, 5(1), 8-19.

[21] http://www.interpol.int/public/DisasterVictim/guide/default.asp.

[22] De Valck, E. Major incident response: collecting ante-mortem data. Forensic Sci. Int., 2006, 159(Suppl 1), S15-9.

[23] Andersen Torpet, L. DVI System International: software assisting in the Thai tsunami victim identification process. J. Forensic Odontostomatol., 2005, 23(1), 19-25.

[24] Brenner, C.H. Some mathematical problems in the DNA identification of victims in the 2004 tsunami and similar mass fatalities. Forensic Sci. Int., 2006, 157(2-3), 172-80.

[25] Clement, J.G.; Winship, V.; Ceddia, J.; Al-Amad, S.; Morales, A.; Hill, A.J. New software for computer-assisted dental-data matching in Disaster Victim Identification and long-term missing persons investigations: "DAVID Web". Forensic Sci. Int., 2006, 159(Suppl 1), S24-9.

[26] Ladika, S. South Asia tsunami. DNA helps identify missing in the tsunami zone. Science, 2005, 307(5709), 504.

[27] http://www.interpol.int/Public/asiandisaster/background/TTVI_FAQ. asp.

[28] http://www.inet.co.th/tsunami/procedures.php.

[29] Beauthier, J.-P.; Boxho, P.; Crèvecoeur, J.M.; Leclercq, M.; Lefèvre, P.; Vogels, L. Mission du team belge au Kosovo, science et justice à la rencontre du drame humain - premiers résultats. Biomed. Hum. Anthropol., 2000, 18(1-2), 43-8.

[30] Ludes B, Tracqui A, Pfitzinger H, Kintz P, Levy F, Disteldorf M, Hutt JM, Kaess B, Haag R, Memheld B, Kaempf C, Friederich F, Evenot E, Mangin P. Medico-legal investigations of the Airbus, A320 crash upon Mount Ste-Odile, France. J. Forensic Sci., 1994, 39(5), 1147-52.

[31] Hirsch, C,S.; Shaler, R. 9/11 through the eyes of a medical examiner. J. Investig. Med., 2002, 50(1), 1-3.

[32] Goodman, N.R.; Edelson, L.B. The efficiency of an X-ray screening system at a mass disaster. J. Forensic Sci., 2002, 47(1), 127-30.

[33] Kieser, J.A.; Laing, W.; Herbison, P. Lessons learned from largescale comparative dental analysis following the South Asian tsunami of 2004. J. Forensic Sci., 2006, 51(1), 109-12.

[34] Messmer, J.M. The use of mammographic equipment in mass disaster identification. J. Forensic Sci., 1982, 27(3), 723-5.

[35] Rutty, G.N.; Robinson, C.E.; Bouhaidar, R.; Jeffery, A.J.; Morgan, B. The role of mobile computed tomography in mass fatality incidents. J. Forensic Sci., 2007, 52(6), 1343-9.
[36] Gill JR. 9/11 and the New York City Office of Chief Medical Examiner. Forensic Sci. Med. Pathol., 2006, 2(1), 29-32.

[37] Perrier, M.; Bollmann, M.; Girod, A.; Mangin, P. Swiss DVI at the tsunami disaster: Expect the unexpected. Forensic Sci. Int., 2006 159, Suppl: S30-2.

[38] http://www.who.int/hac/events/tsunamiconf/presentations/2_16_forensic_pongruk_doc.pdf.

[39] www.paho.org/English/DD/PED/PungrukWHO_Lima.ppt.

[40] Kirsch, H.-P.; Rötzscher, K.; Grundmann, C.; Lessig, R. The Tsunami Disaster in the Kingdom of Thailand 2004. Int. Poster J. Dent. Oral Med., 2007, 9(3), 370.

[41] Biesecker, L.G.; Bailey-Wilson, J.E.; Ballantyne, J.; Baum, H.; Bieber, F.R.; Brenner, C.; Budowle, B.; Butler, J.M.; Carmody, G.; Conneally, P.M.; Duceman, B.; Eisenberg, A.; Forman, L.; Kidd, K.K.; Leclair, B.; Niezgoda, S.; Parsons, T.J.; Pugh, E.; Shaler, R.; Sherry, S.T.; Sozer, A.; Walsh, A. Epidemiology. DNA identifications after the 9/11 World Trade Center attack. Science, 2005, 310(5751), 1122-3.

[42] Deng, Y.J.; Li, Y.Z.; Yu, X.G.; Li, L.; Wu, D.Y.; Zhou, J.; Man, T.Y.; Yang, G.; Yan, J.W.; Cai da, Q.; Wang, J.; Yang, H.M.; Li, S.B.; Yu, J. Preliminary DNA identification for the Tsunami victims in Thailand. Genomics Proteomics Bioinformatics, 2005, 3(3), 143-57.

[43] Hinchliffe, J.A. Disaster dentistry. Br. Dent. J., 2007, 202(8), 4934.

[44] Leclair, B.; Fregeau, C.J.; Bowen, K.L.; Fourney, R.M. Enhanced kinship analysis and STR-based DNA typing for human identification in mass fatality incidents: the Swissair flight 111 disaster. $J$. Forensic Sci., 2004, 49(5), 939-53.

[45] Leclair, B.; Shaler, R.; Carmody, G.R.; Eliason, K.; Hendrickson, B.C.; Judkins, T.; Norton, M.J.; Sears, C.; Scholl, T. Bioinformatics and human identification in mass fatality incidents: the world trade center disaster. J. Forensic Sci., 2007, 52(4), 806-19.

[46] Salo, S.; Salo, H.; Liisanantti, A.; Reponen, J. Data transmission in dental identification of mass disaster victims. J. Forensic Odontostomatol., 2007, 25(1), 17-22.

[47] Schuller-Gotzburg, P.; Suchanek, J. Forensic odontologists successfully identify tsunami victims in Phuket, Thailand. Forensic Sci. Int., 2007, 171(2-3), 204-7.

[48] Tack, L.C.; Thomas, M.; Reich, K. Automated forensic DNA purification optimized for FTA card punches and identifiler STR-based PCR analysis. Clin. Lab. Med., 2007, 27(1), 183-91.

[49] http://www.upi.com/Top_News/2008/12/24/Unidentified-dead-inThai-tsunami-at-388/UPI-85381230142146/. 